\title{
ARBITRATION CLAUSE IN A CONTRACT FOR PUBLIC PROCUREMENT Sabin Ivanov SUBEV
}

\author{
"Vasil Levski" National Military University, Veliko Tarnovo, Bulgaria, \\ subev@abv.bg
}

\begin{abstract}
One of the essential issues in the field of public procurements are the disputes, arisen between the Assigning authority and the participant, selected for a contractor in pursuance of the implementation of the concluded contact for public procurement. The paper considers the possibility of looking at the disputes in a contract according to a public procurement of arbitration.
\end{abstract}

\section{Keywords: public procurement, contract, arbitration, legislation}

\section{Introduction}

One of the essential issues in the field of public procurements are the disputes, arisen between the Assigning authority and the participant, selected for a contractor in pursuance of the implementation of the concluded contact for public procurement. The award of a public procurement is a complex process, containing administrative and civil phase. During the first phase of conducting the procedures, envisaged by the law, it has to be determined a contractor of the public procurement and to be clarified the main elements from the future contract. During the second phase the contract has to be signed and implemented.[1] Therefore the Assigning authority of a public procurement also falls within a dual legal framework - in the first phase, during the selection of a contractor, the Assigning authority has functions of administrative authority and during the second phase- as a counter party under the contract - the Assigning authority appears subject of the Civil law. [2]

In the course of the administrative procedure for selection of contractor, with whom to be concluded the contract for award of a public procurement, the
Assigning authority has to propose a draft contract as a part of the documentation for participation in the public procurement.[3] Upon submission of the bids an element from the mandatory contents of each bid appears declaration for acceptance of the conditions in the draft contract. [4] In case a participant does not agree with the contract conditions, proposed by the Assigning authority and he has not submitted such declaration, the participant shall be subject of elimination from the procedure on the grounds of art. 691 paragraph 1 from the Public procurement act. If the participant declares his disagreement with the conditions proposed by the Assigning authority, in such case he shall be subject of elimination from the procedure on the grounds of art. 691 paragraph 3 from the Law on public procurement. In any case the Assigning authority appears the party, which has the power to determine all conditions under the contract for public procurement except for those, falling within the scope of the assessable part of the bidprice, term for implementation, warranty period, period for after-sale maintenance and etc. 
The jurisdiction in case of dispute, connected with the contract implementation is an element, which ought to be determined by the Assigning authority upon development of the draft contract, part from the documentation for participation. Normally the Assigning authorities often miss that important clause from the contract and refer to the general normative framework in the civil legislation.

The settlement of disputes according to the general court procedures includes three instance court proceedings and considering the Bulgarian judicial system it takes years.

The issue would be settled easily if an arbitral clause is included into the draft contract for a public procurement.

The arbitration is form of alternative settlement of issue from a third party or parties (arbitrator, arbitrators), authorized by the parties under the dispute to have this particular power. [5]

The arbitral proceedings appear out-ofcourt procedure, based on a contract for arbitration, called Arbitration agreement. The arbitration appears form of non-state, contractual, private administration of justice for settlement mainly of disputes in the field of the civil law.[6] Subject of arbitral proceedings may appear also commercial disputes, to which are made equal the disputes under contracts for public procurements. [7]

The opportunity for the parties under a contract for public procurement to address an arbitration for settlement of a legal dispute is contained in art. 19, paragraph 1 from the Civil procedure code, according to which: „The parties under dispute for property may have an agreement for the dispute to be settled by an arbitral court, except if the dispute concerns rights-in-rem or possession over immovable property, allowance or rights under labor relation. "

According to professor Luyben Kornezov, the arbitration is the most prominent form of the dispositive beginning in the civil procedure. According to art. 6 from the $\mathrm{CPC}$ "the court proceedings start upon request of the interested parties", as the matter of the case and the volume of the owed defense and cooperation shall be determined by the parties. So we may come to the conclusion that the arguing parties are not obliged to address the state court, they can seek other ways for settling the disputes between them. One of the above-mentioned alternative ways appears the arbitration. [8] The arbitration has many advantages in comparison with the traditional court proceedings:

By avoiding the competence of the regular state courts, the parties give the dispute in the hands of non-state judicial authority, which they trust. The court of arbitration hears only those disputes, which have been delegated to it by the parties under the contract.

The parties take participation in the constitution of the determining authority through the selection of the arbiters. The trust in the person, who shall settle the dispute, the trust in his honesty, impartiality, and morality are an essential motive for the arguing parties to accept the arbitral award.

The dispute settlement happens according to a simplified procedure, which is known to both parties in advance. They can modify it and adjust it to the peculiarities of the dispute.

The quickness appears one of the most important advantages of the arbitration. The procedure is in one instance only. The disputes are settled within 6 months maximum.

The arbitral awards are final, they are subject of voluntary enforcement, and they are steady because they can be challenged only before the Supreme court of cassation, based on explicitly envisaged reasons.

The arbitral proceedings are more economic. The collected fee is not a fixed rate, it decreases when the claim increases. The expenditures for defense, experts, and translators are made only in one instance.

The arbitral case is not public, it is confidential. Therefore the arbitration is able to avoid deterioration in the relations between the parties. The materials under the 
case are given only to the party, its legal representative, or its representative ad item. The case is heard at the presence of the parties only and other participants in it, as it can be settled only in camera/closed session.

The arbitration is not affected by the restrictions of the international jurisdiction of the state courts, nor is it affected by the local jurisdiction of the national legislation.

The innocent party under the contract can avoid the necessity, inconvenience, expenditures, and inequality to bring a suit against the other party abroad or in other settlement.

Because of the fact that both parties have accepted the arbitration, the probability for them to keep their good business relations is higher.

According to art.1, paragraphs 1 and 2 from the New York convention on the recognition and enforcement of foreign arbitral awards, [9] "This Convention shall apply to the recognition and enforcement of arbitral awards made in the territory of a State other than the State where the recognition and enforcement of such awards are sought, and arising out of differences between persons, whether physical or legal. It shall also apply to arbitral awards not considered as domestic awards in the State where their recognition and enforcement are sought. 2. The term "arbitral awards" shall include not only awards made by arbitrators appointed for each case but also those made by permanent arbitral bodies to which the parties have submitted. "The conclusion drawn from the above recitals is that the enforcement of the arbitral awards abroad is guaranteed much more than the enforcement of the court judgments.

Upon proposing an arbitral clause in the draft contract for public procurement, the Assigning party specifies also the arbitral court, preferred by it, as the interested parties, willing to submit a bid should conform to this preference of the Assigning authority.
The indicative text of the arbitral clause should contain reference to the arbitral proceedings and to point the arbitral court, chosen by the Assigning party: "All disputes, arising out of or in connection with this contract or additional annexes to it, including those arising out of or concerning its interpretation, invalidity, performance or termination shall be settled amicably. If not agreement is reached the dispute shall be referred for resolution to the Court of Arbitration at the Bulgarian Chamber of Commerce and Industry in accordance with the Rules for expedient procedure".

It is disputable the issue whether the contract for public procurement appears an "administrative contract". According to some authors, it has exactly such nature. [10] other authors support the opposite opinion. [11] According to them, the consequences from the concluded contract for public procurement are of civil nature and the jurisdiction for their validity, enforcement, termination or breaking is for the civil court. The fact that the state has some privileges towards the counterpart under the contract doesn't make the contract administrative as far as such similar prevailing position may be seen also under contracts, concluded between other legal subjects of the civil law. [12]

Regardless of the contract type and the fact that one of the parties under it appears public body, there is no statutory restriction for the dispute regarding the validity, enforcement, termination or breaking the contract for public procurement to be awarded to a non-state subject as appears the arbitral court. To the contrary, the prevailing position of the Assigning party of public procurements in the procedure on selection of contractor provides to it the unlimited opportunity to select in advance not only the arbitral court, but also the arbitrators. I would not recommend the last (option), as long as in the procedure for assignment of a public procurement may take participation all interested parties and possible tconnection between the contractor 
and the arbitrator would lead to vitiation of the arbitral proceedings and would lead to the necessity in the draft contract to be envisaged an option for selection of reserve judges in case of challenge of the preliminary chosen judge.

As a summary we may come to the conclusions that the Assigning party of public procurements has the legal opportunity to include an arbitral clause into the draft contract for public procurement and such opportunity provides many advantages if compared to the standard court proceedings.

\section{References}

[1] Analogical in cases of concessions - Ruling 8555 of 09.07.20108 under adm. case № 4748/2008 of Supreme administrative court, IV dep. Reporting judge: Adelina Kovacheva.

[2] Zinovieva, Darina, Discussion theses in the administrative law and procedure, Ciela, Sofia 2009, p.25.

[3] Art. 28, paragraph 1, p. 9 from the Public procurement act, SG, issue 28 of 06.04 .2004 and subsequent amendments.

[4] Art. 56, paragraph 1, p. 12 from the Public procurement act.

[5] Kornezov, Luyben, Civil proceedings, second volume - court and out-of-court proceedings, Sofi-R, Sofia, 2010, p. 19.

[6] Ibidem.

[7] Argument from art. 365, p. 2 from the Civil procedure code, SG, issue 59 of 20.07 .2007 and subsequent amendments.

[8] Kornezov, Luyben, Civil proceedings, second volume - court and out-of-court proceedings, Sofi-R, Sofia, 2010, p. 19.

[9] SG issue 2 of 08.01.1965.

[10] Buchkova, Pamela, „The administrative contract - substantial, procedural and comparative-legal aspects“, Feneya, S. 2012.

[11] Slavova M., V. Petrov, The administrative-procedure code - critical review of the case law, comment and proposals for improvement of the legislation. Feneya, S. 2014.

[12] The quoted work, p. 51 